\title{
Radiocarbon-Based Source Apportionment of Carbonaceous Aerosols at a Regional Background Site on Hainan Island, South China
}

Yan-Lin Zhang, ${ }^{\dagger, \ddagger, \S, \|}$ Jun Li, $"$ Gan Zhang,,${ }^{\prime}$ Peter Zotter, ${ }^{\ddagger}$ Ru-Jin Huang, Jian-Hui Tang, ${ }^{\perp}$ Lukas Wacker, André S H Prévôt, ${ }^{\ddagger}$ and Sönke Szidat ${ }^{*}{ }^{\dagger}, \S$

${ }^{\dagger}$ Department of Chemistry and Biochemistry, University of Bern, 3012 Berne, Switzerland

${ }^{\ddagger}$ Laboratory of Atmospheric Chemistry, Paul Scherrer Institute (PSI), 5232 Villigen-PSI, Switzerland

${ }^{\S}$ Oeschger Centre for Climate Change Research, University of Bern, 3012 Berne, Switzerland

"State Key Laboratory of Organic Geochemistry, Guangzhou Institute of Geochemistry, Chinese Academy of Sciences, 510640 Guangzhou, China

${ }^{\perp}$ Yantai Institute of Coastal Zone Research, Chinese Academy of Sciences, 264003Yantai, China

\#Laboratory of Ion Beam Physics, ETH Zurich, 8093 Zurich, Switzerland

\section{Supporting Information}

ABSTRACT: To assign fossil and nonfossil contributions to carbonaceous particles, radiocarbon $\left({ }^{14} \mathrm{C}\right)$ measurements were performed on organic carbon (OC), elemental carbon (EC), and water-insoluble OC (WINSOC) of aerosol samples from a regional background site in South China under different seasonal conditions. The average contributions of fossil sources to EC, OC and WINSOC were $38 \pm 11 \%, 19 \pm 10 \%$, and $17 \pm 10 \%$, respectively, indicating generally a dominance of nonfossil emissions. A higher contribution from fossil sources to EC $(\sim 51 \%)$ and OC $(\sim 30 \%)$ was observed for air-masses transported from Southeast China in fall, associated with large fossil-fuel combustion and vehicle emissions in highly urbanized regions of China. In contrast, an increase of the nonfossil contribution by $5-10 \%$ was observed during the periods with enhanced open biomass-burning activities in Southeast Asia or Southeast China. A modified EC tracer method was used to estimate the secondary organic carbon from fossil emissions by determining ${ }^{14} \mathrm{C}$-derived fossil WINSOC and fossil

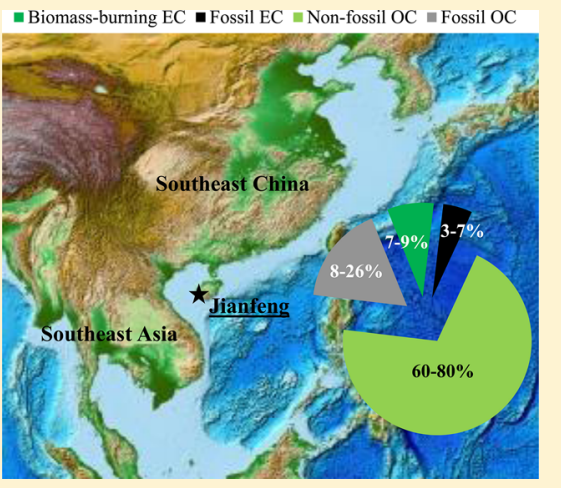
EC. This approach indicates a dominating secondary component $(70 \pm 7 \%)$ of fossil OC. Furthermore, contributions of biogenic and biomass-burning emissions to contemporary OC were estimated to be $56 \pm$ $16 \%$ and $44 \pm 14 \%$, respectively.

\section{INTRODUCTION}

Carbonaceous particles, which contribute $10-70 \%$ to the atmospheric fine particulate matter, ${ }^{1,2}$ are of worldwide concern due to their effects on climate and human health. ${ }^{3,4}$ The complex content of carbonaceous particles (total carbon, TC) is commonly classified into elemental carbon (EC) and organic carbon (OC). EC derives from incomplete combustion of fossil fuels or biomass, and it shows an overall warming effect by either absorbing incoming solar radiation in the atmosphere or by reducing the albedo of surface (i.e., snow and ice). OC can be directly emitted as primary OC (POC) or secondary OC (SOC) from anthropogenic and natural sources. ${ }^{5}$ OC generally triggers a cooling effect by reflecting incoming sunlight. ${ }^{6}$ In addition, some organic species such as polycyclic aromatic hydrocarbons are carcinogens and toxins, ${ }^{3}$ and EC may be coated by those toxic and carcinogenic OC compounds which increases the potential risk for human health. ${ }^{7}$

Therefore, a detailed knowledge of sources of OC and EC is necessary to implement mitigation strategies for their reductions. Radiocarbon $\left({ }^{14} \mathrm{C}\right)$ analysis is a powerful tool to unambiguously distinguish fossil and nonfossil sources of carbonaceous particles. ${ }^{8,9}$ All fossil-fuel emissions such as petroleum and coal combustion are ${ }^{14} \mathrm{C}$-free, whereas nonfossil emissions (e.g., biogenic emissions, biomass burning, cooking) contain the contemporary ${ }^{14} \mathrm{C}$ content. The difference of the ${ }^{14} \mathrm{C}$ levels of fossil and contemporary materials is independent of individual emission conditions or subsequent chemical transformations in the atmosphere. As OC and EC typically originate from diverse sources with different fossil/nonfossil shares, ${ }^{14} \mathrm{C}$ measurements of $\mathrm{OC}$ and $\mathrm{EC}$ as well as some other subfractions such as water-soluble OC (WSOC) and waterinsoluble OC (WINSOC) provide more information for the

Received: November 15, 2013

Revised: February 5, 2014

Accepted: February 7, 2014

Published: February 7, 2014 
apportionment of their sources than ${ }^{14} \mathrm{C}$ analysis of $\mathrm{TC}$ alone. $^{10-18}$

Aerosols emitted from highly polluted regions such as Asia enhance not only the local/regional pollution levels, ${ }^{19-22}$ but may also ascend to the free troposphere, and be transported across the Pacific Ocean to North America, making it a global concern. $^{23}$ However, relative contributions from biomass/ biofuel burning and fossil-fuel combustion are not wellknown in this region with its increasing demand of energy due to growing population and economy growth. Using a ${ }^{14} \mathrm{C}$ source apportionment approach, Sheesley et al. $(2012)^{24}$ found that $73 \pm 6 \%$ and $59 \pm 5 \%$ of EC is from biomass combustion in Maldives and India, respectively. Recently, Chen et al. (2013) used "top-down" ${ }^{14} \mathrm{C}$ measurements in urban sites to determine that fossil combustion is responsible for $80 \pm 6 \%$ of EC in East China. ${ }^{25}$ However, ${ }^{14} \mathrm{C}$ measurement of specific carbonaceous aerosol fractions (i.e., OC, EC, WINSOC, and WSOC) in fine particles has not been reported in South China to our knowledge. In this work, $\mathrm{PM}_{2.5}$ samples (particulate matter with an aerodynamic diameter $<2.5 \mu \mathrm{m}$ ) were collected from May 2005 to Aug 2006 at Mt. Jianfeng (JF), on Hainan Island, South China. This is a regional background receptor site as it is influenced by air pollution outflows from mainland China and Southeast Asia. The objectives of this paper are (1) to directly discriminate and quantify carbon originating from fossil fuel and nonfossil sources by measuring ${ }^{14} \mathrm{C}$ in different carbonaceous subfractions with a newly modified thermaloptical method; (2) to examine how long-range atmospheric transport of both fossil and biomass-burning particulate pollutants from Southeast Asia influences on the regional aerosol burden in South China.

\section{EXPERIMENTAL SECTION}

Sampling Site. JF $\left(18^{\circ} 40^{\prime} \mathrm{N}, 108^{\circ} 49^{\prime} \mathrm{E}, 820 \mathrm{~m}\right.$ ASL $)$ is situated at the southwest of Hainan Island, the southernmost province of China (Figure 1). It is located about $20 \mathrm{~km}$ west of the coast of Beibu Gulf (Gulf of Tonkin), $120 \mathrm{~km}$ northeast from Sanya (the second largest city of Hainan Province) and $315 \mathrm{~km}$ southeast from Haikou (the capital city of Hainan Province). The sampling site is located in a Long-term Research Station of Chinese Tropical Forest Ecosystem with a total area of $475 \mathrm{~km}^{2}$ of tropical evergreen monsoon forest. Detailed information about this site can be found elsewhere. ${ }^{26}$ It is expected that local pollution nearby has very limited influence on this site as the nearest town is approximately 10 $\mathrm{km}$ away. Anthropogenic emissions and biomass burning transported from South China and Southeast Asia are the two major potential sources at this site. ${ }^{27} \mathrm{JF}$ is therefore an ideal receptor site to study air-pollution outflows from mainland China, as well as the impact of Southeast Asian biomass-burning emission through long-range atmospheric transport.

Sampling Procedure. $\mathrm{PM}_{2.5}$ samples were collected at the rooftop of a building (field observational station operated by the Chinese Academy of Forest) using high-volume samplers (Andersen Instruments/GMW) operated at a flow of $\sim 1.1 \mathrm{~m}^{3}$ / min for $24 \mathrm{~h}$. 67 Samples were collected about one sample every week from May 2005 to August 2006 on prebaked (6 h at $650{ }^{\circ} \mathrm{C}$ ) quartz microfiber filters (Whatman, $20.3 \times 25.4 \mathrm{~cm}$ ). The filters were individually wrapped in aluminum foils, packed in airtight polyethylene bags and stored at $-20{ }^{\circ} \mathrm{C}$ for chemical analysis. Four field blanks were treated in the same way as the samples except that the collection time was only $15 \mathrm{~s}$.

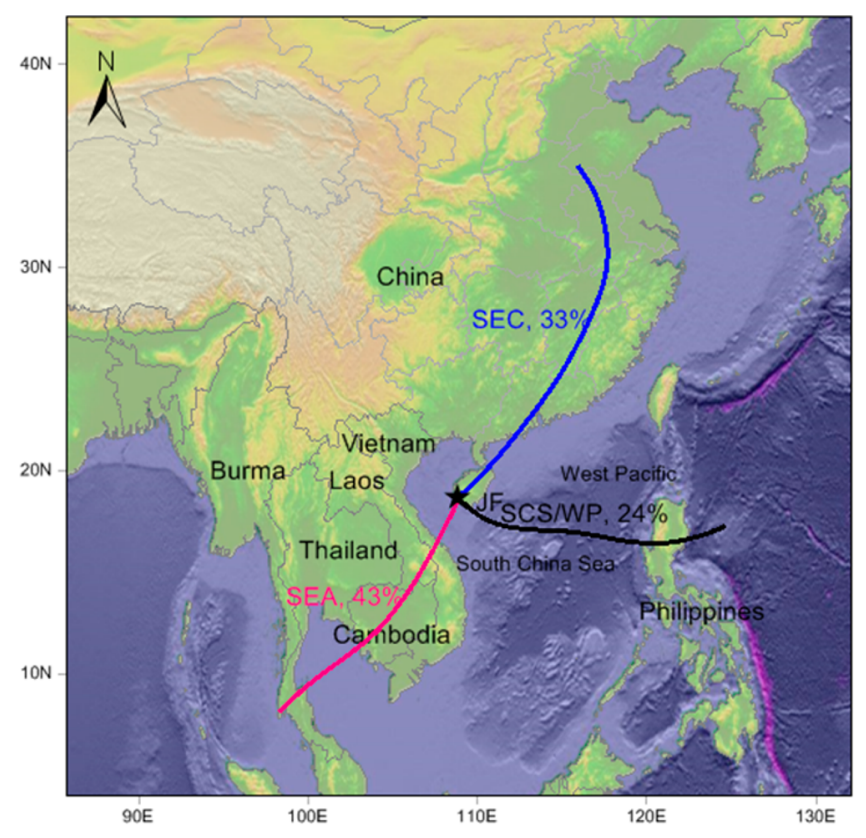

Figure 1. The location of the sampling site (JF) in this study. The backward trajectory types including South China Sea/West Pacific (SCS/WP), Southeast China (SEC) and Southeast Asia (SEA) with occurrence percentage of trajectories ending at the sampling site during the entire sampling period are denoted, as described in the text (see Section 2.5). The classification for clustered air mass origins by data and season is shown in Table S1 and Figure S6 (Supporting Information).

Thermal-Optical Carbon Analysis. Small punches (1.5 $\mathrm{cm}^{2}$ ) of the filter samples were taken for the analysis of the OC and EC mass concentrations by a thermal-optical carbon analyzer (Sunset Laboratory Inc., Tigard, OR) with a modified NIOSH (National Institute of Occupational Safety and Health) thermal-optical transmission protocol, which was described in detail by refs 28,29 . The replicate analysis of samples provided a good analytical precision with relative deviations of 4.4, 9.1, and $4.2 \%$ for OC, EC, and TC, respectively. The average field blank concentration of $\mathrm{OC}$ was approximately $2.0 \pm 1.0 \mu \mathrm{g} / \mathrm{cm}^{2}$ (equivalent to $\sim 0.5 \mu \mathrm{g} / \mathrm{m}^{3}$ ), and EC blank was undetectable. The reported OC concentrations have been subtracted for the average field blank.

${ }^{14} \mathrm{C}$ Analysis of the Carbonaceous Fractions. A thermaloptical OC/EC analyzer (Model4L, Sunset Laboratory Inc.) equipped with a nondispersive infrared (NDIR) detector was used for the isolation of different carbon fractions for subsequent ${ }^{14} \mathrm{C}$ measurements using a four-step thermal-optical protocol Swiss 4S. The method is described in detail in Zhang et al. (2012). ${ }^{3 \sigma}$ Briefly, OC was isolated at $375{ }^{\circ} \mathrm{C}$ within $150 \mathrm{~s}$ from untreated filters in an oxidizing atmosphere $\left(\mathrm{O}_{2}\right.$, 99.9995\%), whereas WINSOC was separated under the same conditions but from water-extracted filters. WSOC was deduced from subtraction of OC and WINSOC based on mass and isotope-mass balancing. $\mathrm{EC}$ was isolated by the combustion of the remaining carbonaceous material at $760{ }^{\circ} \mathrm{C}$ within $150 \mathrm{~s}$ in $\mathrm{O}_{2}(99.9995 \%)$ after complete $\mathrm{OC}$ removal (i.e., $475{ }^{\circ} \mathrm{C} 180 \mathrm{~s}$ in $\mathrm{O}_{2}, 450{ }^{\circ} \mathrm{C} 180$ s and $650{ }^{\circ} \mathrm{C} 180$ s in $\mathrm{He}$ ) from water-extracted filters. The water-extraction treatment (see Supporting Information (SI)) is a prerequisite to isolate EC for ${ }^{14} \mathrm{C}$ measurement as this step can minimize the EC positive artifact from OC charring. ${ }^{30,31}$ In a recent study, we found that 
the negative EC artifact due to the premature EC loss during a harsh OC removal procedure (e.g., combustion of samples at $375{ }^{\circ} \mathrm{C}$ for $4 \mathrm{~h}$ or longer) before EC isolation would potentially overestimate fossil contribution of EC up to $\sim 70 \%$, if only $\sim 20 \%$ EC was recovered. ${ }^{30}$ The EC recovery for ${ }^{14} \mathrm{C}$ measurement in this work was $80 \pm 5 \%$, thus presenting almost the entire continuum of EC.

After the separation of the desired carbonaceous aerosol fractions, the resulting $\mathrm{CO}_{2}$ was trapped cryogenically and sealed in glass ampules for ${ }^{14} \mathrm{C}$ measurement. ${ }^{14} \mathrm{C}$ measurement was conducted by the accelerator mass spectrometer MICADAS equipped with a gas ion source ${ }^{32}$ to omit graphitization step, allowing measuring ${ }^{14} \mathrm{C}$ directly in $\mathrm{CO}_{2}$ from 2 to $100 \mu \mathrm{g}$. All ${ }^{14} \mathrm{C}$ results were expressed as fraction of modern $\left(f_{M}\right)$, that is, the fraction of the ${ }^{14} \mathrm{C} /{ }^{12} \mathrm{C}$ ratio of the sample related to the isotopic ratio of the reference year $1950 .{ }^{33}$ This data was then corrected for ${ }^{14} \mathrm{C}$ decay during the period between 1950 and the year of measurement. The $f_{M}$ value for samples from fossil sources is characterized by $f_{M}=0$ due to the extinction of ${ }^{14} \mathrm{C}$ with a half-life of 5730 years. The $f_{\mathrm{M}}$ values of the contemporary carbon sources including biogenic and biomass burning ( $f_{\mathrm{M}, \mathrm{bio}}$ and $f_{\mathrm{M}, \mathrm{bb}}$, respectively) are larger than 1 due to the nuclear-bomb excess in the $1950 \mathrm{~s}$ and $1960 \mathrm{~s},{ }^{12,34}$ which were estimated for samples in $2005 / 2006$ to be $1.13 \pm 0.05$ and $1.060 \pm 0.015$ for $f_{\mathrm{M}, \mathrm{bb}}$ and $f_{\mathrm{M}, \mathrm{bio}}$ respectively. The value of $f_{M, b b}$ was estimated by a tree-growth model $^{35}$ including 10-year, 20-year, 40-year, 70-year, and 85year old trees with weights of $0.2,0.2,0.4,0.1$, and 0.1 , respectively, harvested in 2005 , and the value of $f_{\mathrm{M} \text {,bio }}$ was taken from the long-term series of ${ }^{14} \mathrm{CO}_{2}$ measurements at the Schauinsland station. ${ }^{34}$ The $f_{M}$ of nonfossil $\left(f_{M, n f}\right)$ of EC equals $f_{\mathrm{M}, \mathrm{bb}}$, given that biomass-burning combustion is the only nonfossil source of EC. The $f_{\mathrm{M}, \mathrm{nf}}$ of OC was determined as the average of $f_{\mathrm{M}, \mathrm{bb}}$ and $f_{\mathrm{M} \text {,bio }}$ assuming that contemporary $\mathrm{OC}$ originates equally from biogenic emissions and biomass burning. Relative contribution of biomass-burning and biogenic emissions to nonfossil OC has very little impact on $f_{M}$ reference compared to other measurement uncertainties. ${ }^{31}$ It should be noted that the uncertainty of source-specific contributions are dependent on the selected $f_{\mathrm{M}}$ reference values. By varying reference $f_{M}$ ratios by \pm 0.05 , the uncertainty is typically within $5 \%$. In addition, $f_{M}(\mathrm{OC})$ was corrected by the average field blank with $f_{\mathrm{M}}$ of $0.65 \pm 0.01(n=2)$ following an isotopic mass balance approach. ${ }^{36}$ And $f_{M}(\mathrm{EC})$ reported here was corrected for the premature EC loss during the OC removal step with an approach described in ref 30 . The typical uncertainties of source apportionment results arise from analytical uncertainties (i.e., OC/EC mass and isotope measurements), blank correction, the variability of reference $f_{\mathrm{M}, \mathrm{nf}}$ values and recoveries of different carbon fractions and approximately amounted to $\pm 15 \%, \pm 20 \%, \pm 20 \%$, and $\pm 15 \%$ for fossil $\mathrm{EC}\left(\mathrm{EC}_{\mathrm{f}}\right)$, biomass-burning $\mathrm{EC}\left(\mathrm{EC}_{\mathrm{bb}}\right)$, fossil $\mathrm{OC}$ $\left(\mathrm{OC}_{\mathrm{f}}\right)$, and nonfossil OC $\left(\mathrm{OC}_{\mathrm{nf}}\right)$, respectively.

Backward Trajectory Analyses. Five-day backward trajectories were calculated using Gridded Meteorological Data combined with the Geographic Information System (GIS) based software, Trajstat ${ }^{37}$ with programs for visualizing meteorological fields and the HYSPLIT4.8 module (http:// www.arl.noaa.gov/HYSPLIT.php). All trajectories ended at the sampling site were calculated at an interval of $6 \mathrm{~h}$ with an arrival height of 100, 500, and $1000 \mathrm{~m}$ during the $24 \mathrm{~h}$ sampling period. The National Centers for Environmental Prediction and the National Center for Atmospheric Research (NCEP/NCAR) reanalysis meteorological data archives from National Oceanic and Atmospheric Administration (NOAA) (ftp://arlftp.arlhq. noaa.gov/pub/archives/reanalysis) were used as the input. According to the origin of the air masses and their transport pathways, the trajectories were then classified into three major categories: (1) South China Sea or Western Pacific (SCS/WP), (2) Southeast Asia (SEA), and (3) Southeast China (SEC). The mean trajectories calculated from the height of $100 \mathrm{~m}$ of each cluster are displayed in Figure 1.

\section{RESULTS AND DISCUSSION}

Concentrations and Temporal Variation. The mass concentrations of OC and EC ranged from 1.17 to $16.03 \mu \mathrm{g} / \mathrm{m}^{3}$ and 0.19 to $1.17 \mu \mathrm{g} / \mathrm{m}^{3}$, with the median values of $4.12 \mu \mathrm{g} / \mathrm{m}^{3}$ and $0.56 \mu \mathrm{g} / \mathrm{m}^{3}$, respectively. The OC and EC concentrations were comparable to those at the high-altitude site of Mt. Abu in India with annual-average abundances of $\mathrm{OC}$ and $\mathrm{EC}$ values of $3.7 \pm 2.4 \mu \mathrm{g} / \mathrm{m}^{3}$ and $0.5 \pm 0.5 \mu \mathrm{g} / \mathrm{m}^{3}$, respectively, ${ }^{38}$ but slightly higher than those values measured at CAWNET (China Atmosphere Watch Network) western remote background stations in China, such as at Zhuzhang (OC and EC averaged $3.1 \pm 0.91 \mu \mathrm{g} / \mathrm{m}^{3}$ and $0.34 \pm 0.18 \mu \mathrm{g} / \mathrm{m}^{3}$, respectively) and Akdala (OC and EC averaged $2.8 \pm 1.2$ and $0.36 \pm 0.31$, respectively). ${ }^{39}$ The carbonaceous aerosols concentrations at JF were apparently lower than those at Manora Peak, India (OC and EC averaged $8.7 \pm 4.5$ and $1.1 \pm 0.7$, respectively) $)^{38}$ and Kathmandu valley, Nepal (OC and EC averaged $4.8 \pm 4.4$ and $1.0 \pm 0.8 \mu \mathrm{g} / \mathrm{m}^{3}$, respectively) in South Asia. ${ }^{40}$

The time-series of the $\mathrm{OC}$ and EC concentrations over the 16-month period is plotted in Figure 2. OC and EC

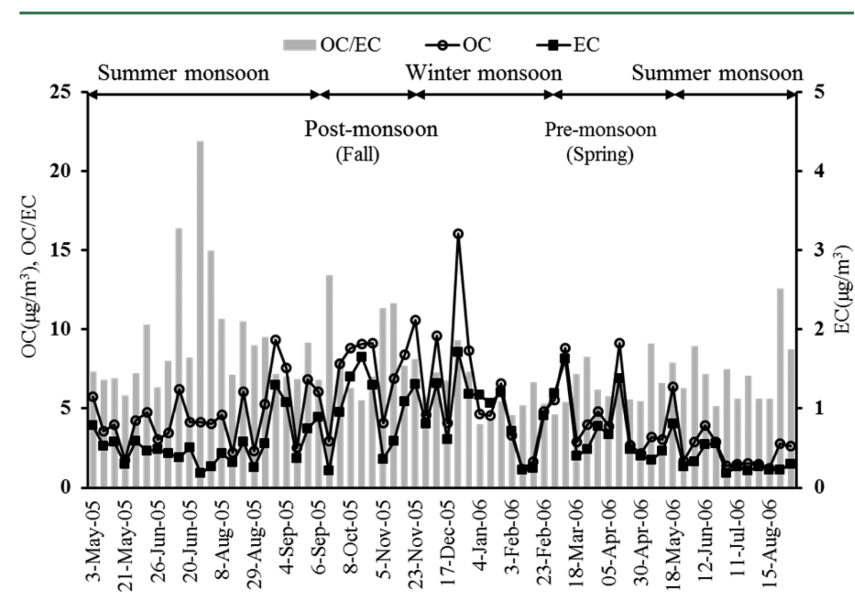

Figure 2. Temporal variations of $\mathrm{OC}, \mathrm{EC}$ concentrations $\left(\mu \mathrm{g} / \mathrm{m}^{3}\right)$ and the $\mathrm{OC} / \mathrm{EC}$ ratios.

concentrations were significantly lower $(p<0.05)$ during the wet summer-monsoon season (i.e., OC and EC averaged from the mid-May to August is $3.93 \pm 1.31 \mu \mathrm{g} / \mathrm{m}^{3}$ and $0.41 \pm 0.13$ $\mu \mathrm{g} / \mathrm{m}^{3}$, respectively) and spring (i.e., OC and EC averaged from March to mid-May is $4.58 \pm 2.22 \mu \mathrm{g} / \mathrm{m}^{3}$ and $0.73 \pm 0.41$ $\mu \mathrm{g} / \mathrm{m}^{3}$, respectively) than in fall (i.e., OC and EC averaged from September to mid-November is $6.65 \pm 2.34 \mu \mathrm{g} / \mathrm{m}^{3}$ and $0.88 \pm 0.45 \mu \mathrm{g} / \mathrm{m}^{3}$, respectively) and winter (i.e., OC and EC averaged from mid-November to February is $6.62 \pm 4.26$ $\mu \mathrm{g} / \mathrm{m}^{3}$ and $0.94 \pm 0.44 \mu \mathrm{g} / \mathrm{m}^{3}$, respectively). The lower concentrations of carbonaceous aerosols during summer have also been reported at Manora Peak/Nainitial, Nepal, ${ }^{38}$ which was attributed to wet deposition of aerosols and low emissions. 

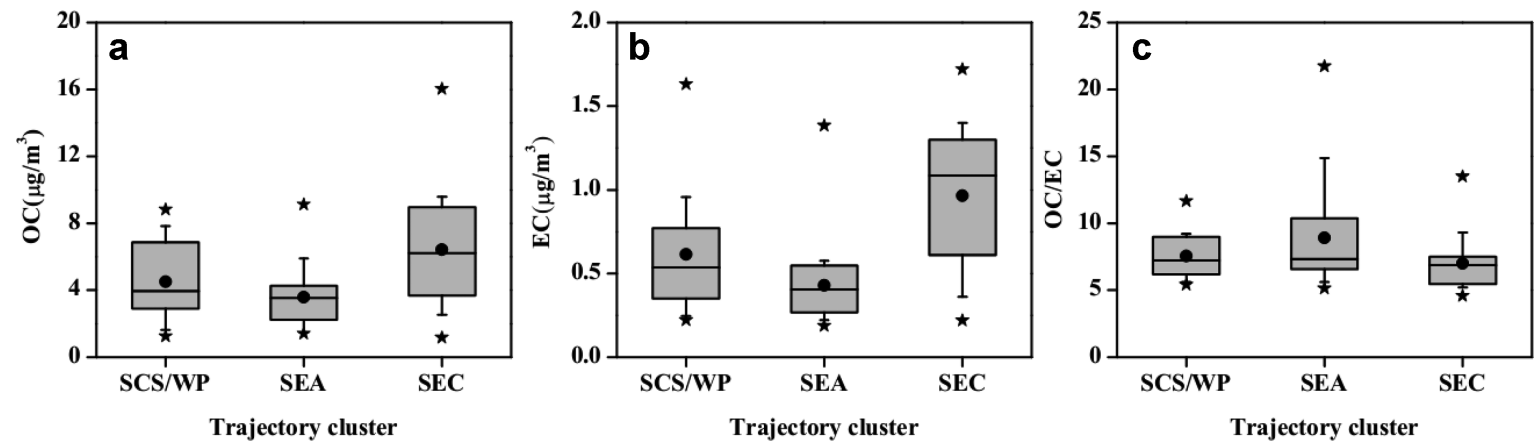

Figure 3. Whisker-box plots of concentrations of OC (a), EC (b) and OC/EC (c) for different clusters of backward trajectories including South China Sea/West Pacific (SCS/WP), Southeast China (SEC) and Southeast Asia (SEA). The box represent the 25th (lower line), 50th (middle line) and 75th (top line) percentiles; the solid dots within the box represent the mean values; the end of the vertical bars represent the 10th (below the box) and 90th (above the box) percentiles; the solid stars represents the maximum and minimum values.

In this season, the air-mass transport was characterized by the prevailing southeasterly or southwesterly flows in association with clean marine air, consistent with the trajectory analysis below. In spring, the prevailing winds are southwestern or southeastern, and the air masses passed over Southeast Asia, which is less developed than SE China, and biomass burning is commonly found in this season. ${ }^{41,42}$ The high abundances of $\mathrm{OC}$ and EC in winter are most likely due to limited wet deposition during the dry condition and air pollution from the coastal and mainland of South China. The increasing of biofuel combustion for household heating in the cold season may increase the aerosols emissions as well.

OC-to-EC Ratios. OC was significantly correlated with EC $\left(\mathrm{R}^{2}=0.77, p<0.05\right.$; SI, Figure $\left.\mathrm{S} 2\right)$, suggesting they may have similar sources. The OC/EC ratios in this study ranged from 4.0 to 13.4 (excluding two data points with ratio above 15 ) with an average of 7.3. They are significantly higher than typical mean OC/EC ratios (range from about 2.6 to 3.6) for fossilfuel dominated aerosols in Chinese urban cities but were in the similar range of the OC/EC ratios (range from about 4 to 13) in regions dominated by biomass burning. ${ }^{39,43} \mathrm{Cao}$ et al. $(2006)^{44}$ also reported a calculated OC/EC ratio of 7.1 for the open biomass-burning inventory in China. ${ }^{44}$ Elevated OC/EC ratios (with an average of 9.3) were found during summer, which is likely associated with an enhanced photochemical SOC formation compared to other seasons. Interestingly, we also observed moderately high $\mathrm{OC} / \mathrm{EC}$ ratios in winter, which was likely due to increased OC from biomass burning (see following sections) along with SOC formation.

Effect of Long-Range Transport and Open Biomass Burning. As there are minor emissions of carbonaceous aerosol around the observation site, the large variability of OC and EC implies that the air quality of this regional background site could be frequently perturbed by long-range transport of air pollution, especially for air masses from Southeast China and Southeast Asia. The whisker box plots (Figure 3) show the concentrations of OC and EC for air masses originating from the three different groups of trajectories (see Section 2.5). The significant increase in both OC and EC is associated with the samples when highly polluted air masses traveled over the continent and the coast of SEC, where numerous industrialized and urbanized regions are located (e.g., the Pearl River Delta). This can be explained by the enhanced anthropogenic emissions from coal burning, biomass/biofuel combustion, cooking and vehicle emissions in this source region. ${ }^{19,39,44,45}$ Besides the relative clean air mass origin, the lower concentrations of OC and EC for the clusters SCS/WP and SEA were also caused by wet deposition during the summer monsoon season. However, two elevated samples (i.e., 12 March and 12 April, 2006) were also found for these two clusters, very likely caused by biomass burning in Southeast Asia, which will be explained in the following.

Five-day backward trajectories showed that the air masses had passed through open satellite-derived biomass burning regions (fire counts) of Southeast China (Jiangxi, Fujian and Guangdong) before reaching JF on 24 Dec, 2005 (SI, Figure S3). The fire counts were detected by MODIS (moderate resolution imaging spectroradiometer) on the NASA satellites and the active fire data are available by online request (http:// earthdata.nasa.gov/firms). This observation was in line with the fact that the concentrations of OC and EC on that day were the highest during the entire study period. It should be noted that biofuels (including crop residues and fuel wood) are one of the major energy sources in the southeastern provinces of China. ${ }^{46}$ Besides, fossil sources such as vehicular emission and coal combustion from Southeast China may contribute additionally to aerosol loadings at this clean site following the NE wind, which was also reported by Zhang et al. (2010). ${ }^{27}$ With the ${ }^{14} \mathrm{C}$ measurements in different carbonaceous fractions, however, the relative contributions of fossil and nonfossil sources to carbonaceous particles can be directly quantified only in this study (see Section 3.4). Similarly, the air masses passed through the regions of Vietnam, Cambodia and Laos and Thailand before reaching the sampling site on $12 \mathrm{Apr}, 2006$, where open biomass burning occurred intensively (SI, Figure S4). High concentrations of OC and EC were found for this sample, but this enhancement was lower compared to winter conditions. Huang et al. (2012) ${ }^{47}$ have recently reported biomass-burning emissions in spring 2006, which showed a peak in March and April when high active biomass burning occurred in most regions of SE Asia increasing the OC and EC loadings at a remote site in Southern Taiwan by long-range transport.

${ }^{14} \mathrm{C}$-Based Source Apportionment. ${ }^{14} \mathrm{C}$ Results, Fraction of Modern. A subset of $8 \mathrm{PM}_{2.5}$ samples (two samples from each season) and two field blanks were selected for ${ }^{14} \mathrm{C}$ measurements (SI, Figure S5). The sample information, as well as the results of the fraction of modern $\left(f_{M}\right.$, see Section 2.4) of different carbonaceous fractions (i.e., EC, OC, WINSOC and WSOC) are compiled in Table S2 (SI). The values for $f_{\mathrm{M}}(\mathrm{EC})$ range from 0.52 to 0.86 with a mean of $0.69 \pm 0.13$. For all samples, $f_{M}(\mathrm{OC})$ values (mean $\left.0.87 \pm 0.10\right)$ were higher $(p<$ $0.01)$ than the corresponding $f_{M}(\mathrm{EC})$ values, indicating larger 
relative nonfossil contribution to OC. This prevalence may be caused by biogenic POC and SOC formation, which even could contribute substantially in winter due to the relatively high temperatures $\left(13-18{ }^{\circ} \mathrm{C}\right)$ at this tropical-forested site during sampling periods, or by substantial biomass-burning emissions and cooking, which are characterized by higher OC/EC ratios compared to ambient fossil emissions from traffic (e.g., 6.25 compared to 1.47 from ${ }^{12}$ ).

In this study, OC was further divided into two subfractions according to their water solubility, that is, WSOC and WINSOC for their ${ }^{14} \mathrm{C} /{ }^{12} \mathrm{C}$ determinations since WINSOC better represents primary organic carbon, whereas WSOC is a major portion of SOC, biomass-burning OC and/or aged OC. ${ }^{15,48,49}$ The $f_{M}$ (WSOC) at this receptor site ranged from 0.66 to 1.02 with an average of $0.87 \pm 0.13$. High $f_{M}$ (WSOC) values were also reported for aerosols collected at other rural sites in Asia such as $\mathrm{MCOH}$, Maldives (0.91-1.01) and Sinhagad, India $(0.85-0.90) .{ }^{15}$ The lowest $f_{M}($ WSOC $)$ at the JF site was observed in fall, which may be associated with aging and secondary formation of fossil emissions during long-range transport from urban regions in Southeast China. This is corroborated by Ding et al. (2012), ${ }^{50}$ who recently reported that $>75 \%$ of SOC stemmed from aromatic precursors during fall and winter in the Pearl River Delta (PRD), South China, one of the most industrialized and densely populated regions in China. From a few available ${ }^{14} \mathrm{C}$ studies of WINSOC, $f_{M}$ (WINSOC) was found in nearly every case to be lower than the corresponding $f_{M}$ (WSOC) for aerosols at rural sites of Millbrook, NY and Harcum, VA, ${ }^{51}$ and urban sites at Zurich and Bern in Switzerland. ${ }^{52,53}$ But such a trend $\left(f_{M}\right.$ (WSOC) > $f_{M}($ WINSOC $)$ ) was not observed in this study, likely due to large contribution of biomass burning to both WSOC and WINSOC.

Source Apportionment of EC. ${ }^{14} \mathrm{C}$ results of EC show that the contribution of fossil source to total $\mathrm{EC}\left(\mathrm{EC}_{\mathrm{f}}\right)$ ranged from $25 \%$ to $56 \%$ with an average of $38 \%$, whereas the nonfossil contribution, that is, biomass-burning combustion ( $\left.\mathrm{EC}_{\mathrm{bb}}\right)$ contribution amounted $44 \%$ to $75 \%$ with an average of $62 \%$ (Figure 4). In order to study the impact of long-range transport on source characteristic of aerosols at the JF site, ${ }^{14} \mathrm{C}$-based source apportionment results with different source regions are shown in Figure 5. Higher $\mathrm{EC}_{\mathrm{f}}$ mass concentration was associated with samples with air-mass origin from SEC, which is

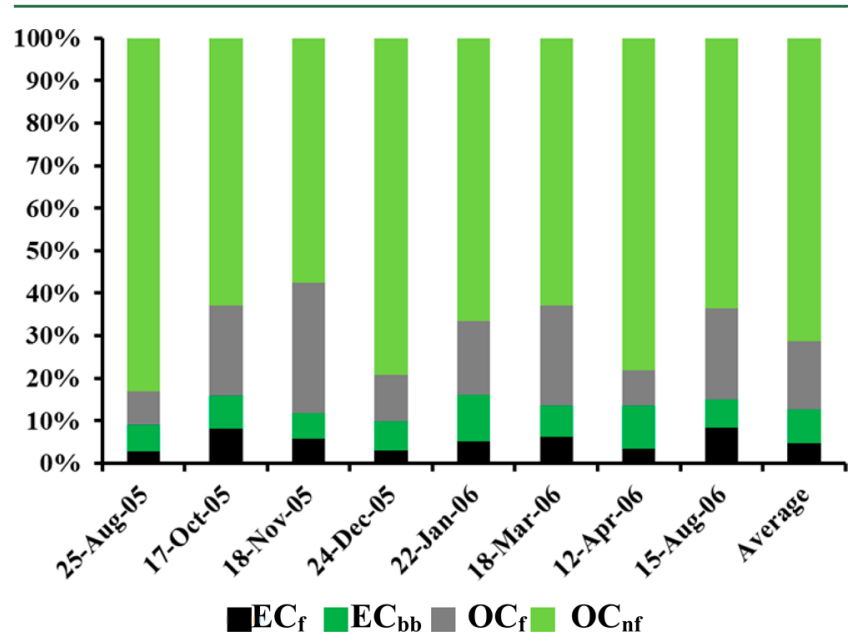

Figure 4. Relative source apportionment of $\mathrm{OC}$ and $\mathrm{EC}$ by ${ }^{14} \mathrm{C}$ measurements.

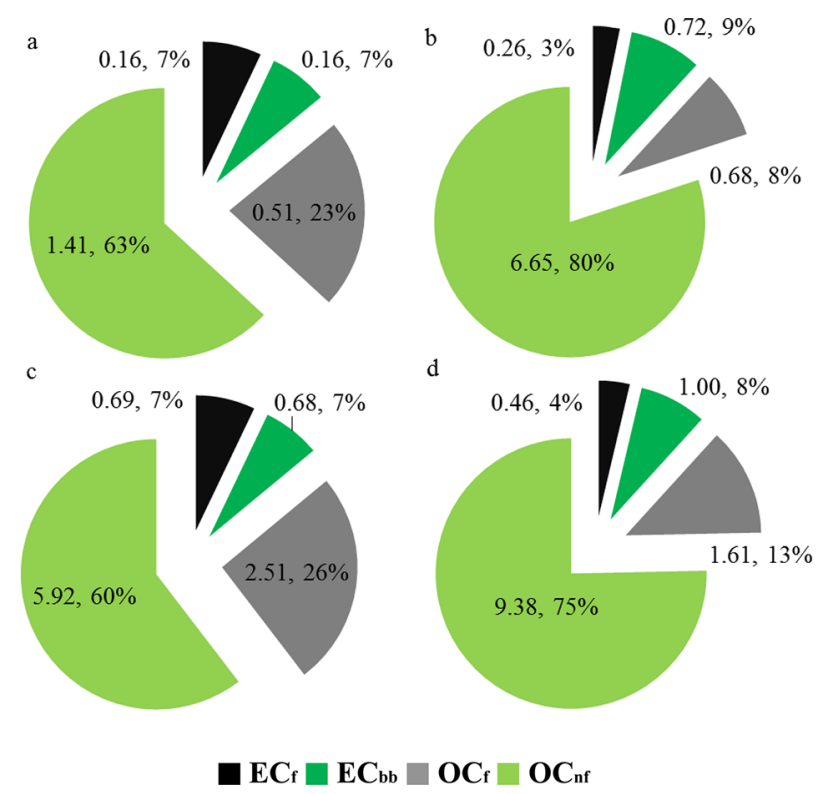

Figure 5. Fossil (f) and nonfossil (nf) fractions (concentrations in $\mu \mathrm{g} / \mathrm{m}^{3}$ and \% of TC, $n=2$ ) of OC and EC for samples from different source regions according to air-mass back trajectory clusters (as described in the text), corresponding to South China Sea/Western Pacific (SCS/WP) (a), Southeast Asia (SEA) (b) and Southeast China (SEC). The air mass origin of SEC was further divided into fall (or postmonsoon) (c) and winter seasons (d).

consistent with the fact that EC emitted from coal combustion and vehicular emissions is higher in this region. The fossil contribution was higher in fall than in winter when the samples with air mass origin from SEC were further apportioned into the most frequent seasons, i.e., fall and winter (Figure 5). The relative contribution from $\mathrm{EC}_{\mathrm{f}}$ was unexpectedly large for the samples with air masses originating in or traveling over SCS/ WP oceanic sources, which is likely due to minor local/ continental emissions (e.g., from Hainan province and Philippines) and/or extensive shipping activities in this region. However, both the absolute $\mathrm{EC}_{\mathrm{f}}$ and $\mathrm{EC}_{\mathrm{bb}}$ concentrations were still substantially lower than the concentrations with air mass origin from other source regions. For the samples with air-mass origin from SEA, $73 \% \pm 6 \%$ of EC stemmed from biomass combustion, which may include burning of biofuels, agricultural crop residues and forests. The comparison of samples with air mass origins from SCS/WP and SEA for spring and summer indicated a clear dependence on the source regions, whereas a distinct seasonality could not be observed (SI Figure S6).

Source Apportionment of OC. OC was dominated by nonfossil sources with a mean contribution of $81 \%$, ranging from $65 \%$ to $91 \%$ with the highest fossil contribution in fall (Figure 4). In contrast, the highest contribution from nonfossil OC $\left(\mathrm{OC}_{\mathrm{nf}}\right)$ was found for samples with air masses origin in SEA and attributed to high biomass/biofuel combustion (Figure 5). Interestingly, the fraction of $\mathrm{OC}_{\mathrm{nf}}$ was higher in winter than in fall for samples with air masses from SEC, an area where traffic-related emissions are assumed to be a major contributor to OC. ${ }^{54,55}$ Such a high nonfossil contribution could be attributed to large open biomass-burning activities (see Section 3.3) and/or widespread use of biomass burning as residential heating and cooking in rural areas of SEC during the sampling time. This hypothesis is corroborated by Zhang et al. $(2010 \mathrm{c})^{56}$ that found biomass/biofuel-burning activities in the 
rural parts of the PRD and neighboring regions have a significant impact on ambient urban aerosol levels. The absolute fossil $\mathrm{OC}\left(\mathrm{OC}_{\mathrm{f}}\right)$ concentrations in the samples with air masses originating from SEC were higher than those from SCS/WP and SEA by a factor of 2 to 5 , although the relative fossil contribution was not elevated. This means that also the absolute $\mathrm{OC}_{\mathrm{nf}}$ concentrations were higher by a factor $2-5$ for air masses from SEC compared to the other two regions.

Estimation of SOC. It is difficult to quantify POC and SOC due to the vast number of organic compounds with a variety of chemical and physical properties. However, it is possible to use an indirect method for the quantitative assessment of SOC, as the EC tracer method proposed by Turpin and Huntzicker $(1995)^{57}$ and Castro et al. (1999): ${ }^{58}$

$$
\mathrm{SOC}=\mathrm{OC}-(\mathrm{OC} / \mathrm{EC})_{\mathrm{pri}} \times \mathrm{EC}
$$

The minimum OC/EC ratio during the sampling periods is often assumed as the primary OC/EC ratio ((OC/EC) pri) when SOC is unlikely to be produced. Nevertheless, some limitations exist related to the capability of this method. First, a differentiation of SOC from photochemically altered POC $^{5}$ is hardly possible by such simple techniques. Second, this approach could not be applied directly, as SOC formation may occur throughout all sampling periods with tropical climate conditions on the one hand and long-range transport of biomass-burning emissions can substantially lead to a higher $\mathrm{OC} / \mathrm{EC}$ ratio on the other hand. Both factors would lead to biased estimations of SOC. ${ }^{50}$ As a result, it is necessary to exclude effects from both biomass burning and SOC formation at this site before using the EC tracer method to estimate SOC. Here, a modified EC tracer method is used to estimate the fossil-derived SOC formation with the measurement of fossil WINSOC (WINSOC $\mathrm{f}$ ) and $\mathrm{EC}_{\mathrm{f}}$ by ${ }^{14} \mathrm{C}$ analysis. Since the majority of fossil OC is water insoluble, ${ }^{13,53}$ and this approach excludes WSOC contribution which is often from biomass burning or SOC formation. ${ }^{48,49}$ As shown in Figure 6,

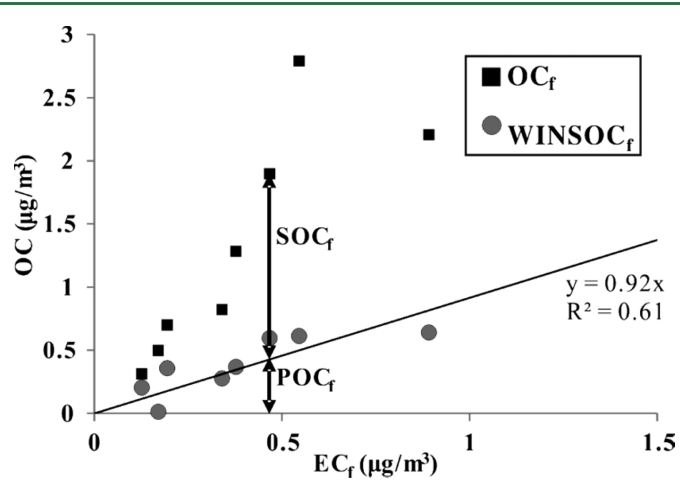

Figure 6. $\mathrm{OC}_{\mathrm{f}}$ and $\mathrm{WINSOC}_{\mathrm{f}}$ as a function of $\mathrm{EC}_{\mathrm{f}}$. The regression line estimates the $(\mathrm{OC} / \mathrm{EC})_{\mathrm{pri}, \mathrm{f}}$ emission ratio for assigning the $\mathrm{OC}_{\mathrm{f}}$ content of individual samples into $\mathrm{POC}_{\mathrm{f}}$ and $\mathrm{SOC}_{\mathrm{f}}$.

WINSOC $_{\mathrm{f}}$ correlate well with $\mathrm{EC}_{\mathrm{f}}$. Although one has found lower values in a tunnel, ${ }^{59}$ the slope of 0.92 is in the range of urban sites in China $(0.87-1.06 \text { for OC/EC) })^{39}$ and also similar to $\mathrm{OC} / \mathrm{EC}$ at other urban sites for purely primary emissions (e.g., refs 1, 60, and 61). It is worthy to note that a much higher primary OC/EC ratio $(\sim 4.0)$ would be obtained if considering both WINSOC and WSOC fractions; however, such a high ratio is very unlikely. Consequently, $\mathrm{WINSOC}_{\mathrm{f}}$ was used as a tracer of fossil POC $\left(\mathrm{POC}_{\mathrm{f}}\right)$ so that the slope of 0.92 estimates realistically the primary $\mathrm{OC} / \mathrm{EC}$ ratio from fossil-fuel sources $\left((\mathrm{OC} / \mathrm{EC})_{\text {priff }}\right)$. The consistency of this value with the literature suggests that the contribution of photochemically altered $\mathrm{POC}_{\mathrm{f}}$ is minor. The fossil-derived $\mathrm{SOC}\left(\mathrm{SOC}_{\mathrm{f}}\right)$ results as

$$
\mathrm{SOC}_{\mathrm{f}}=\mathrm{OC}_{\mathrm{f}}-(\mathrm{OC} / \mathrm{EC})_{\mathrm{pri}, \mathrm{f}} \times \mathrm{EC}_{\mathrm{f}}
$$

This approach reveals an average $\mathrm{SOC}_{\mathrm{f}}$ contribution to $\mathrm{OC}_{\mathrm{f}}$ of $70 \% \pm 7 \%$, which indicates a dominating secondary component of fossil OC for all samples. In contrast to $(\mathrm{OC} / \mathrm{EC})_{\mathrm{pri}, \mathrm{f}}$, however, the approximation of OC/EC ratio for nonfossil sources is more complicated and less confident because of a large variation of OC/EC emission ratios of nonfossil sources. In addition, wood burning POC is partially water-soluble. Therefore, $\mathrm{OC}_{\mathrm{nf}}$ component was not further apportioned into POC and SOC.

Source Apportionment of Nonfossil OC. In contrast, the apportionment of $\mathrm{OC}_{\mathrm{nf}}$ into biogenic $\mathrm{OC}\left(\mathrm{OC}_{\text {bio }}\right)$ and biomassburning $\mathrm{OC}\left(\mathrm{OC}_{\mathrm{bb}}\right)$ is more robust and has been used in previous studies. ${ }^{12,31,62}$ As given in, ${ }^{12} \mathrm{OC}_{\mathrm{bb}}$ can be estimated from $\mathrm{EC}_{\mathrm{bb}}$ (see Section 3.4.2) and an assumed ratio for OC/EC in biomass burning emissions, that is, $(\mathrm{OC} / \mathrm{EC})_{\mathrm{bb}}$, following:

$$
\mathrm{OC}_{\mathrm{bb}}=\mathrm{EC}_{\mathrm{bb}} \times(\mathrm{OC} / \mathrm{EC})_{\mathrm{bb}}
$$

Excess contemporary OC (nonfossil sources excluding biomass-burning sources) was then defined as $\mathrm{OC}_{\mathrm{bio}}$ :

$$
\mathrm{OC}_{\mathrm{bio}}=\mathrm{OC}_{\mathrm{nf}}-\mathrm{OC}_{\mathrm{bb}}
$$

Therefore, a determination of $(\mathrm{OC} / \mathrm{EC})_{\mathrm{bb}}$ is a crucial point to determine $\mathrm{OC}_{\mathrm{bb}}$, since a wide range of $(\mathrm{OC} / \mathrm{EC})_{\mathrm{bb}}$ ratios can be found in literature (e.g., 2.5-10). ${ }^{63}$ Nevertheless, a "bestestimate" of 6.3, 5.0, and 3.3 were used as $(\mathrm{OC} / \mathrm{EC})_{\mathrm{bb}}$ ratios for samples collected at Zurich, Birmingham and Barcelona, respectively. ${ }^{12,31,62}$ Here, with the average $(\mathrm{OC} / \mathrm{EC})_{\mathrm{bb}}$ ratio of $5.0 \pm 1.5$, the relative shares of biogenic and biomassburning sources to $\mathrm{OC}_{\mathrm{nf}}$ are estimated semiquantitatively as $44 \pm 14 \%$ and $56 \pm 16 \%$. A more quantitative determination is not possible due to the dependence of $(\mathrm{OC} / \mathrm{EC})_{\mathrm{bb}}$ on burning conditions and the lack emission data from this region.

Further, a significant correlation between $\mathrm{EC}_{\mathrm{bb}}$ and nonfossil WSOC was observed $\left(R^{2}=0.94, p<0.01\right.$; SI, Figure S7), implying large contributions of primary or secondary biomassburning sources to $\mathrm{WSOC}_{\mathrm{nf}}$. This finding underlines that $\mathrm{WSOC}_{\mathrm{nf}}$ at the study site was mainly attributed to primary and/ or secondary biomass burning particles (i.e., secondary organic formation from photo-oxidation of volatile organic compounds released from biomass burning emissions and subsequent gasparticle partitioning of the less volatile products), whereas biogenic SOC contribution to WSOC $_{n f}$ was rather small.

Comparisons with Other Sites in Asia and Implications. Table S3 (SI) compiles ${ }^{14} \mathrm{C}$-based source apportionment studies in Asia. Only with an exception at Yufa (located only $\sim 50 \mathrm{~km}$ to Beijing), nonfossil sources were a major contributor of TC at rural or background sites, ranging from $\sim 64$ to $\sim 85 \%$. Lower but still substantial nonfossil contributions (i.e., ranging from $34 \%$ to $49 \%$ for annual mean values) were found at urban or suburban sites in Asia, likely due to common practice of biomass burning for cooking and heating in Asia. ${ }^{14} \mathrm{C}$ measurements of OC and/or EC were only reported in a few comparative studies due to analytical challenges in separation of different carbonaceous fractions. $\mathrm{OC}$ is generally dominated by nonfossil sources, whereas contemporary sources are large if not predominant contributors of EC at the site of JF, which 
underlines the influence of biomass burning/biofuel combustions on EC loading in Southeast China. Although different separation and determination methods were used, other studies in Asian areas such as the Maldives, West India and Japan also reported the importance of biomass-burning contributions to EC (42-73\%, see Table S3 in SI). Even in urban sites, contemporary sources were still considerable despite the importance of contributions from fossil sources to OC and EC. These results imply the relevance of nonfossil sources such as urban food cooking and biomass combustions to urban particles loadings. ${ }^{64}$ In addition, regional biomass combustions including open agricultural residual burning and biofuel combustion for cooking and heating in rural sites could also be considerable contributors to urban particulate matter. Therefore, regulating carbonaceous particles (both OC and EC) and other aerosol emissions not only from fossil sources such as vehicles and industry, but also from biomass/biofuel combustions would be beneficial for air quality in both rural and urban regions of Asia, and also provide a good opportunity to reduce EC's climate warming impact.

Further experiments are needed to constrain sources of carbonaceous particles, and thereby to better constitute and implement relevant regulation policy with respect to climate and human health benefits. This is especially needed in China considering the large but poorly constrained carbonaceous aerosols emissions. We therefore suggest conducting ${ }^{14} \mathrm{C}$ measurements of different carbonaceous particles fractions in combination with other techniques (e.g., organic tracers and aerosol mass spectrometer) in a strategic multisite (including both urban and rural sites) campaign in South or Southeast China.

\section{ASSOCIATED CONTENT}

\section{S Supporting Information}

Water extraction treatment; sampling data and the corresponding air mass back trajectory type; a comparison of ${ }^{14} \mathrm{C}$-based source apportionment studies in Asia; classification for clustered air mass origins by season; the relationship between OC and EC; 5-day air mass backward trajectories and MODIS fire counts nearby on 24-Dec-05 and 12-Apr-06; 5-day air mass backward trajectories for the selected $\mathrm{PM}_{2.5}$ samples for ${ }^{14} \mathrm{C}$ measurements; fossil and nonfossil fractions of OC and EC for samples with different air mass origins from SCS/WP, SEA as well as the breakdown by seasons of spring and summer; nonfossil OC and nonfossil WSOC as a function of biomassburning EC are available. This material is available free of charge via the Internet at http://pubs.acs.org.

\section{AUTHOR INFORMATION}

\section{Corresponding Author}

*Phone: +41 3163143 08; fax: +41 3163143 99; e-mail: szidat@dcb.unibe.ch.

\section{Notes}

The authors declare no competing financial interest.

\section{ACKNOWLEDGMENTS}

This work was supported by the "Strategic Priority Research Program (B)" of the Chinese Academy of Sciences (No. XDB05040503) and the Natural Science Foundation of China (No. 41125014 and 41273117).

\section{REFERENCES}

(1) Lim, H. J.; Turpin, B. J. Origins of primary and secondary organic aerosol in Atlanta: Results' of time-resolved measurements during the Atlanta supersite experiment. Environ. Sci. Technol. 2002, 36 (21), 4489-4496.

(2) Lonati, G.; Ozgen, S.; Giugliano, M. Primary and secondary carbonaceous species in $\mathrm{PM}_{2.5}$ samples in Milan (Italy). Atmos. Environ. 2007, 41 (22), 4599-4610.

(3) Mauderly, J. L.; Chow, J. C. Health effects of organic aerosols. Inhalation Toxicol. 2008, 20 (3), 257-288.

(4) Highwood, E. J.; Kinnersley, R. P. When smoke gets in our eyes: The multiple impacts of atmospheric black carbon on climate, air quality and health. Environ. Int. 2006, 32 (4), 560-566.

(5) Fuzzi, S.; Andreae, M. O.; Huebert, B. J.; Kulmala, M.; Bond, T. C.; Boy, M.; Doherty, S. J.; Guenther, A.; Kanakidou, M.; Kawamura, K.; Kerminen, V. M.; Lohmann, U.; Russell, L. M.; Poschl, U. Critical assessment of the current state of scientific knowledge, terminology, and research needs concerning the role of organic aerosols in the atmosphere, climate, and global change. Atmos. Chem. Phys. 2006, 6, 2017-2038.

(6) Forster, P.; Ramaswamy, V.; Artaxo, P.; Berntsen, T.; Betts, R.; Fahey, D. W.; Haywood, J.; Lean, J.; Lowe, D. C.; Myhre, G., Changes in atmospheric constituents and in radiative forcing. In Climate Change 2007: The Physical Science Basis. Contribution of Working Group I to the Fourth Assessment Report of the Intergovernmental Panel on Climate Change; Solomon, S., Qin, D., Manning, M., Chen, Z., Marquis, M., Tignor, M., Miller, H. L., Eds.; Cambridge University Press: Cambridge, 2007.

(7) Mi, H. H.; Lee, W. J.; Tsai, P. J.; Chen, C. B. A comparison on the emission of polycyclic aromatic hydrocarbons and their corresponding carcinogenic potencies from a vehicle engine using leaded and lead-free gasoline. Environ. Health Perspect. 2001, 109 (12), $1285-1290$.

(8) Currie, L. A. Evolution and multidisciplinary frontiers of ${ }^{14} \mathrm{C}$ aerosol science. Radiocarbon 2000, 42 (1), 115-126.

(9) Szidat, S. Sources of Asian haze. Science 2009, 323 (5913), 470471.

(10) Zencak, Z.; Elmquist, M.; Gustafsson, Ö. Quantification and radiocarbon source apportionment of black carbon in atmospheric aerosols using the CTO-375 method. Atmos. Environ. 2007, 41 (36), 7895-7906.

(11) Gustafsson, O.; Krusa, M.; Zencak, Z.; Sheesley, R. J.; Granat, L.; Engstrom, E.; Praveen, P. S.; Rao, P. S.; Leck, C.; Rodhe, H. Brown clouds over South Asia: Biomass or fossil fuel combustion? Science 2009, 323 (5913), 495-498.

(12) Szidat, S.; Jenk, T. M.; Synal, H.-A.; Kalberer, M.; Wacker, L.; Hajdas, I.; Kasper-Giebl, A.; Baltensperger, U. Contributions of fossil fuel, biomass-burning, and biogenic emissions to carbonaceous aerosols in Zurich as traced by ${ }^{14} \mathrm{C}$. J. Geophys. Res. 2006, 111 (D7), D07206.

(13) Wozniak, A. S.; Bauer, J. E.; Dickhut, R. M.; Xu, L.; McNichol, A. P. Isotopic characterization of aerosol organic carbon components over the eastern United States. J. Geophys. Res. 2012, 117 (D13), D13303.

(14) Zhang, Y. L.; Liu, D.; Shen, C. D.; Ding, P.; Zhang, G. Development of a preparation system for the radiocarbon analysis of organic carbon in carbonaceous aerosols in China. Nucl. Instr. and Meth. in Phys. Res. B. 2010, 268 (17-18), 2831-2834.

(15) Kirillova, E. N.; Andersson, A.; Sheesley, R. J.; Kruså, M.; Praveen, P. S.; Budhavant, K.; Safai, P. D.; Rao, P. S. P.; Gustafsson, Ö. ${ }^{13} \mathrm{C}$ and ${ }^{14} \mathrm{C}$-based study of sources and atmospheric processing of water-soluble organic carbon (WSOC) in South Asian aerosols. J. Geophys. Res. 2013, 118 (2), 614-626.

(16) Liu, D.; Li, J.; Zhang, Y.; Xu, Y.; Liu, X.; Ding, P.; Shen, C.; Chen, Y.; Tian, C.; Zhang, G. The use of levoglucosan and radiocarbon for source apportionment of $\mathrm{PM}_{2.5}$ carbonaceous aerosols at a background site in East China. Environ. Sci. Technol. 2013, 47 (18), 10454-61. 
(17) Wang, G. H.; Zeng, Y. S.; Yao, J.; Qian, Y.; Huang, Y.; Liu, K.; Liu, W.; Li, Y. Source apportionment of atmospheric carbonaceous particulate matter based on the radiocarbon. J. Radioanal. Nucl. Chem. 2013, 295 (2), 1545-1552.

(18) Pavuluri, C. M.; Kawamura, K.; Uchida, M.; Kondo, M.; Fu, P. Q. Enhanced modern carbon and biogenic organic tracers in Northeast Asian aerosols during spring/summer. J. Geophys. Res. 2013, 118 (5), 2362-2371.

(19) Tang, J. H.; Chan, L. Y.; Chan, C. Y.; Li, Y. S.; Chang, C. C.; Liu, S. C.; Li, Y. D., Nonmethane hydrocarbons in the transported and local air masses at a clean remote site on Hainan Island, south China. J. Geophys. Res.: Atmos.. 2007, 112 (D14), D14316. DOI: 10.1029/ 2006JD007796.

(20) Wang, T.; Ding, A. J.; Blake, D. R.; Zahorowski, W.; Poon, C. N.; Li, Y. S. Chemical characterization of the boundary layer outflow of air pollution to Hong Kong during February-April 2001. J. Geophys. Res.: Atmos. 2003, 108 (D20), 8787-8801.

(21) Chan, C. Y.; Wong, K. H.; Li, Y. S.; Chan, L. Y.; Zheng, X. D. The effects of Southeast Asia fire activities on tropospheric ozone, trace gases and aerosols at a remote site over the Tibetan Plateau of Southwest China. Tellus Ser. B-Chem. Phys. Meteorol. 2006, 58 (4), $310-318$.

(22) Venkataraman, C.; Habib, G.; Eiguren-Fernandez, A.; Miguel, A. H.; Friedlander, S. K. Residential biofuels in south Asia: Carbonaceous aerosol emissions and climate impacts. Science 2005, 307 (5714), $1454-1456$.

(23) de Gouw, J. A.; Cooper, O. R.; Warneke, C.; Hudson, P. K.; Fehsenfeld, F. C.; Holloway, J. S.; Hubler, G.; Nicks, D. K.; Nowak, J. B.; Parrish, D. D.; Ryerson, T. B.; Atlas, E. L.; Donnelly, S. G.; Schauffler, S. M.; Stroud, V.; Johnson, K.; Carmichael, G. R.; Streets, D. G. Chemical composition of air masses transported from Asia to the U. S. West Coast during ITCT 2K2: Fossil fuel combustion versus biomass-burning signatures. J. Geophys. Res.: Atmos.. 2004, 109 (D23), D23S20. DOI: 10.1029/2003JD004202.

(24) Sheesley, R. J.; Kirillova, E.; Andersson, A.; Krusa, M.; Praveen, P. S.; Budhavant, K.; Safai, P. D.; Rao, P. S. P.; Gustafsson, O. Yearround radiocarbon-based source apportionment of carbonaceous aerosols at two background sites in South Asia. J. Geophys. Res. 2012, 117, D10202.

(25) Chen, B.; Andersson, A.; Lee, M.; Kirillova, E. N.; Xiao, Q.; Krusa, M.; Shi, M.; Hu, K.; Lu, Z.; Streets, D. G.; Du, K.; Gustafsson, O. Source forensics of black carbon aerosols from china. Environ. Sci. Technol. 2013, 47 (16), 9102-8.

(26) Tang, J. H.; Chan, L. Y.; Chan, C. Y.; Li, Y. S.; Chang, C. C.; Liu, S. C.; Li, Y. D. Nonmethane hydrocarbons in the transported and local air masses at a clean remote site on Hainan Island, south China. J. Geophys. Res. 2007, 112 (D14), D23520.

(27) Zhang, G.; Li, J.; Li, X. D.; Xu, Y.; Guo, L. L.; Tang, J. H.; Lee, C. S. L.; Liu, X. A.; Chen, Y. J. Impact of anthropogenic emissions and open biomass burning on regional carbonaceous aerosols in South China. Environ. Pollut. 2010, 158 (11), 3392-3400.

(28) Zhi, G.; Chen, Y.; Feng, Y.; Xiong, S.; Li, J.; Zhang, G.; Sheng, $\mathrm{G}$.; $\mathrm{Fu}, \mathrm{J}$. Emission characteristics of carbonaceous particles from various residential coal-stoves in China. Environ. Sci. Technol. 2008, 42 (9), 3310-3315.

(29) Chen, Y. J.; Zhi, G. R.; Feng, Y. L.; Liu, D. Y.; Zhang, G.; Li, J.; Sheng, G. Y.; Fu, J. M. Measurements of black and organic carbon emission factors for household coal combustion in China: Implication for emission reduction. Environ. Sci. Technol. 2009, 43 (24), 94959500.

(30) Zhang, Y. L.; Perron, N.; Ciobanu, V. G.; Zotter, P.; Minguillon, M. C.; Wacker, L.; Prevot, A. S. H.; Baltensperger, U.; Szidat, S. On the isolation of OC and EC and the optimal strategy of radiocarbonbased source apportionment of carbonaceous aerosols. Atmos. Chem. Phys. 2012, 12 (22), 10841-10856.

(31) Minguillón, M. C.; Perron, N.; Querol, X.; Szidat, S.; Fahrni, S. M.; Alastuey, A.; Jimenez, J. L.; Mohr, C.; Ortega, A. M.; Day, D. A.; Lanz, V. A.; Wacker, L.; Reche, C.; Cusack, M.; Amato, F.; Kiss, G.; Hoffer, A.; Decesari, S.; Moretti, F.; Hillamo, R.; Teinila, K.; Seco, R.;
Penuelas, J.; Metzger, A.; Schallhart, S.; Muller, M.; Hansel, A.; Burkhart, J. F.; Baltensperger, U.; Prevot, A. S. H. Fossil versus contemporary sources of fine elemental and organic carbonaceous particulate matter during the DAURE campaign in Northeast Spain. Atmos. Chem. Phys. 2011, 11 (23), 12067-12084.

(32) Wacker, L.; Fahrni, S. M.; Hajdas, I.; Molnar, M.; Synal, H. A.; Szidat, S.; Zhang, Y. L. A versatile gas interface for routine radiocarbon analysis with a gas ion source. Nucl. Instrum. Methods Phys. Res., Sect. B 2013, 294, 315-319.

(33) Stuiver, M.; Polach, H. A. Discussion: Reporting of ${ }^{14} \mathrm{C}$ data. Radiocarbon 1977, 19 (3), 355-363.

(34) Levin, I.; Naegler, T.; Kromer, B.; Diehl, M.; Francey, R. J.; Gomez-Pelaez, A. J.; Steele, L. P.; Wagenbach, D.; Weller, R.; Worthy, D. E. Observations and modelling of the global distribution and longterm trend of atmospheric ${ }^{14} \mathrm{CO}_{2}$. Tellus, Ser. B 2010, 62 (1), 26-46.

(35) Mohn, J.; Szidat, S.; Fellner, J.; Rechberger, H.; Quartier, R.; Buchmann, B.; Emmenegger, L. Determination of biogenic and fossil $\mathrm{CO}_{2}$ emitted by waste incineration based on ${ }^{14} \mathrm{CO}_{2}$ and mass balances. Bioresour. Technol. 2008, 99 (14), 6471-6479.

(36) Cao, F.; Zhang, Y.-L.; Szidat, S.; Zapf, A.; Wacker, L.; Schwikowski, M. Microgram-level radiocarbon determination of carbonaceous particles in firn and ice samples: Pretreatment and OC/EC separation. Radiocarbon 2013, 55 (2-3), 383-390.

(37) Wang, Y. Q.; Zhang, X. Y.; Draxler, R. R. TrajStat: GIS-based software that uses various trajectory statistical analysis methods to identify potential sources from long-term air pollution measurement data. Environ. Model. Software 2009, 24 (8), 938-939.

(38) Ram, K.; Sarin, M.; Hegde, P. Atmospheric abundances of primary and secondary carbonaceous species at two high-altitude sites in India: Sources and temporal variability. Atmos. Environ. 2008, 42 (28), 6785-6796.

(39) Zhang, X. Y.; Wang, Y. Q.; Zhang, X. C.; Guo, W.; Gong, S. L., Carbonaceous aerosol composition over various regions of China during 2006. J. Geophys. Res.: Atmos. 2008, 113 (D14), D14111. DOI: 10.1029/2007JD009525.

(40) Stone, E. A.; Schauer, J. J.; Pradhan, B. B.; Dangol, P. M.; Habib, G.; Venkataraman, C.; Ramanathan, V. Characterization of emissions from South Asian biofuels and application to source apportionment of carbonaceous aerosol in the Himalayas. J. Geophys. Res. 2010, 115 (D6), 6301.

(41) Chan, C. Y.; Chan, L. Y.; Harris, J. M.; Oltmans, S. J.; Blake, D. R.; Qin, Y.; Zheng, Y. G.; Zheng, X. D. Characteristics of biomass burning emission sources, transport, and chemical speciation in enhanced springtime tropospheric ozone profile over Hong Kong. J. Geophys. Res. 2003, 108 (D1), 4015.

(42) Streets, D. G.; Bond, T. C.; Carmichael, G. R.; Fernandes, S. D.; Fu, Q.; He, D.; Klimont, Z.; Nelson, S. M.; Tsai, N. Y.; Wang, M. Q.; Woo, J. H.; Yarber, K. F. An inventory of gaseous and primary aerosol emissions in Asia in the year 2000. J. Geophys. Res. 2003, 108 (D21), 8809.

(43) Novakov, T.; Andreae, M. O.; Gabriel, R.; Kirchstetter, T. W.; Mayol-Bracero, O. L.; Ramanathan, V. Origin of carbonaceous aerosols over the tropical Indian Ocean: Biomass burning or fossil fuels? Geophys. Res. Lett. 2000, 27 (24), 4061-4064.

(44) Cao, J. J.; Lee, S. C.; Chow, J. C.; Watson, J. G.; Ho, K. F.; Zhang, R. J.; Jin, Z. D.; Shen, Z. X.; Chen, G. C.; Kang, Y. M.; Zou, S. C.; Zhang, L. Z.; Qi, S. H.; Dai, M. H.; Cheng, Y.; Hu, K. Spatial and seasonal distributions of carbonaceous aerosols over China. J. Geophys. Res. 2007, 112 (D22), D22S11.

(45) Zheng, M.; Wang, F.; Hagler, G. S. W.; Hou, X. M.; Bergin, M.; Cheng, Y. A.; Salmon, L. G.; Schauer, J. J.; Louie, P. K. K.; Zeng, L. M.; Zhang, Y. H. Sources of excess urban carbonaceous aerosol in the Pearl River Delta Region, China. Atmos. Environ. 2011, 45 (5), 1175-1182.

(46) Yan, X. Y.; Ohara, T.; Akimoto, H. Bottom-up estimate of biomass burning in mainland China. Atmos. Environ. 2006, 40 (27), $5262-5273$.

(47) Huang, K.; Fu, J. S.; Hsu, N. C.; Gao, Y.; Dong, X.; Tsay, S.-C.; Lam, Y. F. Impact assessment of biomass burning on air quality in 
Southeast and East Asia during BASE-ASIA. Atmos. Environ. 2013, 78, 291-302.

(48) Weber, R. J.; Sullivan, A. P.; Peltier, R. E.; Russell, A.; Yan, B.; Zheng, M.; de Gouw, J.; Warneke, C.; Brock, C.; Holloway, J. S.; Atlas, E. L.; Edgerton, E. A study of secondary organic aerosol formation in the anthropogenic-influenced southeastern United States. J. Geophys. Res. 2007, 112 (D13), D13302.

(49) Mayol-Bracero, O. L.; Guyon, P.; Graham, B.; Roberts, G.; Andreae, M. O.; Decesari, S.; Facchini, M. C.; Fuzzi, S.; Artaxo, P. Water-soluble organic compounds in biomass burning aerosols over Amazonia - 2. Apportionment of the chemical composition and importance of the polyacidic fraction. J. Geophys. Res. 2002, 107 (D20), D8091.

(50) Ding, X.; Wang, X. M.; Gao, B.; Fu, X. X.; He, Q. F.; Zhao, X. Y.; Yu, J. Z.; Zheng, M., Tracer-based estimation of secondary organic carbon in the Pearl River Delta, south China. J. Geophys. Res. 2012, 117, D05313.

(51) Wozniak, A. S.; Bauer, J. E.; Dickhut, R. M. Characteristics of water-soluble organic carbon associated with aerosol particles in the eastern United States. Atmos. Environ. 2012, 46, 181-188.

(52) Szidat, S.; Jenk, T. M.; Gäggeler, H. W.; Synal, H. A.; Fisseha, R.; Baltensperger, U.; Kalberer, M.; Samburova, V.; Wacker, L.; Saurer, M.; Schwikowski, M.; Hajdas, I. Source apportionment of aerosols by ${ }^{14} \mathrm{C}$ measurements in different carbonaceous particle fractions. Radiocarbon 2004, 46 (1), 475-484.

(53) Zhang, Y. L.; Zotter, P.; Perron, N.; Prévôt, A. S. H.; Wacker, L.; Szidat, S. Fossil and non-fossil sources of different carbonaceous fractions in fine and coarse particles by radiocarbon measurement. Radiocarbon 2013, 55 (2-3), 1510-1520.

(54) Cao, J. J.; Lee, S. C.; Ho, K. F.; Zou, S. C.; Fung, K.; Li, Y.; Watson, J. G.; Chow, J. C. Spatial and seasonal variations of atmospheric organic carbon and elemental carbon in Pearl River Delta Region, China. Atmos. Environ. 2004, 38 (27), 4447-4456.

(55) Zheng, M.; Hagler, G. S. W.; Ke, L.; Bergin, M. H.; Wang, F.; Louie, P. K. K.; Salmon, L.; Sin, D. W. M.; Yu, J. Z.; Schauer, J. J. Composition and sources of carbonaceous aerosols at three contrasting sites in Hong Kong. J. Geophys. Res. 2006, 111 (D20), D20313.

(56) Zhang, Z. S.; Engling, G.; Lin, C. Y.; Chou, C. C. K.; Lung, S. C. C.; Chang, S. Y.; Fan, S. J.; Chan, C. Y.; Zhang, Y. H. Chemical speciation, transport and contribution of biomass burning smoke to ambient aerosol in Guangzhou, a mega city of China. Atmos. Environ. 2010, 44 (26), 3187-3195.

(57) Turpin, B. J.; Huntzicker, J. J. Identification of secondary organic aerosol episodes and quantitation of primary and secondary organic aerosol concentrations during Scaqs. Atmos. Environ. 1995, 29 (23), $3527-3544$.

(58) Castro, L. M.; Pio, C. A.; Harrison, R. M.; Smith, D. J. T. Carbonaceous aerosol in urban and rural European atmospheres: Estimation of secondary organic carbon concentrations. Atmos. Environ. 1999, 33 (17), 2771-2781.

(59) Chirico, R.; Prevot, A. S. H.; DeCarlo, P. F.; Heringa, M. F.; Richter, R.; Weingartner, E.; Baltensperger, U. Aerosol and trace gas vehicle emission factors measured in a tunnel using an Aerosol Mass Spectrometer and other on-line instrumentation. Atmos. Environ. 2011, 45 (13), 2182-2192.

(60) Shah, S. D.; Cocker, D. R., III; Miller, J. W.; Norbeck, J. M. Emission rates of particulate matter and elemental and organic carbon from in-use diesel engines. Environ. Sci. Technol. 2004, 38 (9), 25442550.

(61) Handler, M.; Puls, C.; Zbiral, J.; Marr, I.; Puxbaum, H.; Limbeck, A. Size and composition of particulate emissions from motor vehicles in the Kaisermühlen-Tunnel, Vienna. Atmos. Environ. 2008, 42 (9), 2173-2186.

(62) Heal, M. R.; Naysmith, P.; Cook, G. T.; Xu, S.; Duran, T. R.; Harrison, R. M. Application of ${ }^{14} \mathrm{C}$ analyses to source apportionment of carbonaceous $\mathrm{PM}_{2.5}$ in the UK. Atmos. Environ. 2011, 45 (14), 2341-2348.
(63) Chow, J. C.; Watson, J. G.; Kuhns, H.; Etyemezian, V.; Lowenthal, D. H.; Crow, D.; Kohl, S. D.; Engelbrecht, J. P.; Green, M. C. Source profiles for industrial, mobile, and area sources in the Big Bend Regional Aerosol Visibility and Observational study. Chemosphere 2004, 54 (2), 185-208.

(64) Hodzic, A.; Jimenez, J. L.; Prévôt, A. S. H.; Szidat, S.; Fast, J. D.; Madronich, S. Can 3-D models explain the observed fractions of fossil and non-fossil carbon in and near Mexico City? Atmos. Chem. Phys. 2010, 10 (22), 10997-11016. 